\title{
METHODOLOGY OF FORESIGHT-ANALYSIS IN FORECASTING THE DEVELOPMENT OF INTERNATIONAL TRADE
}

\author{
Ilona Dumanska ${ }^{1}$
}

\begin{abstract}
The purpose of the article is to substantiate the systemic principles of implementation of foresight-analysis of international trade as a method of strategic forecasting at the macro level, the formation of its methodological tools and implementation models. Methodology. The article used general and special research methods. Classification of types of foresight-analysis of the development of international trade and their characteristics, the formation of a set of factors influencing it was based on grouping, synthesis and formalization. Economic modeling, scientific abstraction, systems analysis were used in building a model of foresight-analysis of international trade and identified the factors of negative impact on it. Using the method of coefficients, structural analysis and analytical comparison offers groups of economic indicators of foreign trade to analyze the development of international trade in the preparatory stage of foresight-analysis. Results. It is established that the system of classifications of foresight-analysis allows its application not only at the national level of forecasting the development of trade, but also internationally. It is revealed that when applying the methodology of foresight-analysis of international trade development it is necessary to take into account the purposeful influence of endogenous and exogenous factors. The model of providing the methodology of foresight-analysis of the development of international trade is structured, which includes the following components: system methodology, strategic guidelines, information and analytical support, implementation process and a set of methodological tools. It is found that the combined application of methods (quantitative, qualitative, mixed) in the foresight-analysis of the development of international trade provides maximum efficiency. The addition of the structure of economic methods of foresight-analysis by a group of economic indicators that assess the level of development of foreign trade of a country is substantiated and proposed. Practical implementation. Formation of methodological tools and models for the implementation of foresight-analysis of the development of international trade, taking into account the specifics of foreign trade policy of states based on a consolidated group of economic indicators. Value/originality. The proposed groups of economic indicators can be used in the decomposition of methods of foresight-analysis of international trade to confirm the effectiveness of strategic directions of foreign trade policy and sound forecasting of its effectiveness in the future.
\end{abstract}

Key words: foresight-analysis, international trade, method, forecast, scenario, impact factor, model, economic indicators.

JEL Classification: F17, F47, O24

\section{Introduction}

Governments in many countries recognize the need to plan their future outcomes by formulating national or regional long-term forecasts. Thus effective management of foreign trade policy in dynamic uncertain conditions is possible only on the basis of application of effective mechanisms of forecasting which provide an opportunity to form the strategy of development and an estimation of consequences of the accepted decisions.

Global Foresight Group, the world's leading organization for Foresight, notes on its official website

Corresponding author:

${ }^{1}$ Khmelnytskyi National University, Ukraine.

Email: dumanskaiy@gmail.com

ORCID: https://orcid.org/0000-0003-2449-0633

ResearcherID: Z-1244-2018 that the days of statistical forecasts are over. For a successful decision, it is necessary to significantly expand the boundaries of information processing, to look at the process more comprehensively (Foresight Group, 2021).

Foresight-analysis is the leading technology for choosing future development. Foresight is distinguished from other tools by four main characteristics: consideration of various development alternatives, which is based on the uncertainty of the future; focus on taking specific measures that will allow to shape the 
future as they want to see it; interdisciplinary complex nature, covering the maximum number of factors that may affect future processes; involvement of a wide range of interested diverse groups of experts (Yanch, 1974).

The term "foresight" was first used by science fiction writer Herbert Wells in 1930 during a speech on the BBC (Wells, 1932). As a technology for the practical application of sound prediction, foresight was developed and applied in the 1950s in the American corporation RAND, where the problem of identifying advanced military technologies was solved. RAND specialists developed the Delphi method, which became the basis of foresight research. From the 1970s, foresights of scientific and technological progress began to be conducted abroad and at the national level. Numerous examples of foresight are given by all advanced countries in Europe, the United States and Southeast Asia (Habegger, 2010 and Popper, Keenan, Miles, Butter, Sainz, 2007).

Foresight has gradually become one of the most effective tools for the innovative organization of society. Since the 1990s, foresight has been widely used in advanced countries in public administration, as well as in the development of strategies, projects and programs of regional and local government (Cuosa, 2011).

Foresight-analysis, in contrast to traditional forecasting, acquires special significance at crucial moments when, for some reason, the trends of the previous development of the economic system are broken. This is exactly the crisis that international trade experienced and is currently experiencing during the COVID-19 pandemic, which has exacerbated the need to define a strategy for further development of the world's socio-economic system and intensified attempts by experts to predict its possible scenarios.

\section{Research methodology}

It should be noted that the methodology of foresight has absorbed dozens of traditional and new methods and has its own national specifics. Typically, each of the foresight projects aimed at solving the problems of strategic management, uses a combination of different approaches, including logical-structural approach (LSA), KPI (Key Performance Indicators), project management and their various combinations. In general, foresight is primarily focused on identifying possible options for seeing the future, with the basis for assessing these options is expert analysis, i.e., the main vector of this methodology is aimed at more active and targeted use of expert knowledge (Kuzyk, Kushlin, Yakovets, 2006).

According to Ben Martin (1995), one of the leading ideologues of this technology, Foresight is a systematic effort to study the long-term prospects of science, technology, economics and society in order to identify strategic areas of research and emerging technologies that are highly degree of probability will bring a significant economic and social effect. This definition is quite capacious and has already entered the category of classics.

In turn, French professor of economics Jean Harrow and German economist Kerstin Kuls (1999) present Foresight as a process of building a common perception of trends in the long run, which is characterized by systematicity.

UNIDO's fundamental two-volume book (2005) explains: "Foresight is a systematic attempt to look into the long-term future of science, technology, economics and society to identify areas of strategic research and generic technologies that can deliver the greatest economic and social benefits."

Representatives of the Russian School (Sokolov, 2007 and Gretchenko, 2010) believe that Foresight is a scenario of forecasting of socio-economic development of the economy, industry in 10-20 years, which can be agreed in terms of using scenario methods, but not with the definition as a variety forecasting, because the purpose of Foresight is not prediction but understanding.

Western economists (Eurasian Higher Business School, 2021) and Li SS, Kang MH, Lee LC (2009) write that Foresight in the broad context of "strategic, cautious thinking" is not something new or particularly exotic, but natural and important characteristics of activities related to strategic planning and policy development, which are usually carried out by corporations or government agencies.

An interesting approach is the triangle of vectors of research by the Foresight method (Foresight Group, 2021) presented on the official page of European Foresight. It points to elements such as thinking about the future, discussing it, shaping the future with open assumptions about future development options, stakeholder participation, and proactiveness by supporting future creation.

All researchers emphasize that foresight is a process of constantly refining the vision of the future, which is carried out taking into account the activity of stakeholders involved in its formation. The development and use of the foresight concept is directly related to modern requirements for strategic management. Currently, there are methodological developments of researchers ongroups of indicators and parameters for assessing the quality of business strategy in international trade, which can be used in management to confirm the effectiveness of strategic directions of business development and counteract intuitive decision-making by senior management in this area (Dumanska, 2021), but they are not the basis for forecasting. Instead, only methods of foresight-analysis can effectively prioritize and mobilize participants to develop forecasts in areas such as science and technology, economics, government, and society. 
Several dozen methods have been developed for modern foresight, and despite their significant number, there is no ideal method. Each foresight project uses a combination that is appropriate for the specific practice. The choice of methodology (as a set of methods) is made taking into account the goals, objectives of the project and budgetary resources, qualified experts, political support, the necessary infrastructure and time in accordance with the subject of the study. Today, the methodology of foresight-analysis of international trade is poorly studied, which determines the urgency of substantiating the systemic principles of foresightanalysis of international trade as a method of strategic forecasting at the macro level, the formation of its methodological tools and implementation models.

\section{Specifics of foresight-analysis of international trade development}

Long-term forecasting of international trade in such developed countries as the USA, Great Britain, Germany, France, Japan and many others at the national level is based on the foresight methodology (Kizim, Matyushenko, Shostak, Danova, 2015), which has proven to be an effective tool for setting priorities in this segment of the economy. Obtaining the most objective picture of the future, which meets the interests of all participants in trade relations at the international level, is ensured by the involvement in the foresight process of government officials and intergovernmental world and regional organizations, management of multinational corporations, science and society, which allows historical, political, social-economic and mental features of the organization of trade relations.

The development and use of foresight-analysis is directly related to modern requirements for strategic management, which define it as a process of constantly refining the vision of the future, which is carried out taking into account the activities of stakeholders involved in its formation.

Given the existence of a significant number of types of foresight-analysis, an important point is its division and classification, as well as the choice of criteria for this purpose. The following types are most often distinguished (Luther, 2004):

1) international: allows to define the mission of development at the interstate level;

2) national: interprets development at the country level;

3) regional: definition of desirable directions of development of the region;

4) sectoral: focuses on the development of a particular industry;

5) corporate: covers the development of business entities.

Thus, the system of classifications of foresight-analysis allows its application not only at the national level of forecasting the development of trade in the country, but also internationally. At the same time, a distinctive feature of foresight from other approaches and methods is that its active component is not only to obtain options for the probable future, but also the formation of methods to achieve the optimal of these options, in several scenarios international trade.

Foresight has common features with forecasting. A forecast is a scientifically based judgment about the possible states of an object in the future or about alternative ways and terms of achieving these states. What combines foresight and forecasting is that both methods take into account objective trends and forces that influence development; forecasting methods are used: the Delphi method (expert assessments), scenario planning, expert discussions (focus groups, brainstorming); critical technologies are determined. At the same time, foresight differs significantly from forecasting, as it involves all key participants in development: science and technology, business, government, the public. Scientist (Fedulova, 2008) carry out traditional forecasting.

In addition to this main difference, the following are noted: foresight develops cooperation and collaboration between business, government and scientists; develops the ability and culture of foresight in society; provides the ability to choose a course of action depending on the "vision of the future"; contains elements of active influence on the future, by defining areas of research and the emergence of technologies that can bring the greatest economic and social benefits from the concentration of resources in these areas. Thus, the report of the UN Commission on Science and Technology for Development (2014) provides a brief overview of foresights by region, presented in Table 1 .

Thus, foresight-analysis methodology is widely used in countries around the world as a key tool for the development and implementation of research and innovation policies, including in the field of international trade. At the international level, in the field of international trade, the focus is on foresight, when governments set priorities based on them, create links between science and practice, and in some cases change the system of research organization and management culture.

\section{Building a model of international trade development based on foresight-analysis}

The foresight study of the development of international trade raises the question of the starting point for determining the totality of all internal and external factors in the forecasting and analytical system at the beginning of the study, which determine the algorithm for building its model.

When applying the methodology of foresight-analysis of international trade development, it is necessary to take into account the targeted influence of endogenous and exogenous factors presented in Figure 1. 
Table 1

Top 10 most common foresight methods and frequency of their use by regions of the world

\begin{tabular}{|c|c|c|c|c|c|c|c|}
\hline Foresight methods & $\begin{array}{c}\text { North-West } \\
\text { Europe }(511)\end{array}$ & $\begin{array}{c}\text { Southern } \\
\text { Europe (71) }\end{array}$ & $\begin{array}{c}\text { Eastern } \\
\text { Europe (52) }\end{array}$ & $\begin{array}{c}\text { Latin } \\
\text { America } \\
(107)\end{array}$ & $\begin{array}{c}\text { North } \\
\text { America } \\
(109)\end{array}$ & Asia (89) & Africa (18) \\
\hline Formation of expert panels & $\mathrm{H}$ & $\mathrm{VH}$ & $\mathrm{VH}$ & $\mathrm{VH}$ & $\mathrm{H}$ & A & $\mathrm{H}$ \\
\hline Scenario development & $\mathrm{H}$ & $\mathrm{A}$ & $\mathrm{H}$ & $\mathrm{H}$ & $\mathrm{L}$ & A & $\mathrm{H}$ \\
\hline Trend extrapolation & $\mathrm{H}$ & A & $\mathrm{A}$ & $\mathrm{A}$ & $\mathrm{L}$ & $\mathrm{A}$ & $\mathrm{A}$ \\
\hline Development of the future & A & $\mathrm{L}$ & $\mathrm{A}$ & A & A & $\mathrm{L}$ & $\mathrm{H}$ \\
\hline Brain storm & $\mathrm{A}$ & $\mathrm{H}$ & $\mathrm{H}$ & $\mathrm{A}$ & $\mathrm{L}$ & $\mathrm{A}$ & $\mathrm{H}$ \\
\hline Delphi method & $\mathrm{L}$ & $\mathrm{A}$ & $\mathrm{A}$ & $\mathrm{H}$ & $\mathrm{L}$ & $\mathrm{A}$ & $\mathrm{L}$ \\
\hline Interviewing & $\mathrm{A}$ & $\mathrm{L}$ & $\mathrm{L}$ & A & $\mathrm{L}$ & $\mathrm{L}$ & A \\
\hline $\begin{array}{l}\text { Identification of key } \\
\text { technologies }\end{array}$ & $\mathrm{L}$ & $\mathrm{H}$ & $\mathrm{L}$ & $\mathrm{L}$ & A & A & $\mathrm{L}$ \\
\hline Questionnaire / Poll & $\mathrm{A}$ & $\mathrm{L}$ & A & $\mathrm{A}$ & $\mathrm{L}$ & $\mathrm{L}$ & $\mathrm{H}$ \\
\hline SWOT analysis & $\mathrm{A}$ & $\mathrm{A}$ & $\mathrm{H}$ & $\mathrm{L}$ & $\mathrm{L}$ & $\mathrm{L}$ & $\mathrm{L}$ \\
\hline $\begin{array}{l}\text { Frequency level: } \\
\text { VH - very high; } \mathrm{H} \text { - high; A }\end{array}$ & average; $\mathrm{L}-\mathrm{lo}$ & & \multicolumn{5}{|c|}{ Number of analyzed foresights: $(\ldots)$} \\
\hline
\end{tabular}

Source: United Nations Commission on Science and Technology for Development Strategic (2014). Foresight for the Post-2015 Development Agenda, Geneva, Switzerland

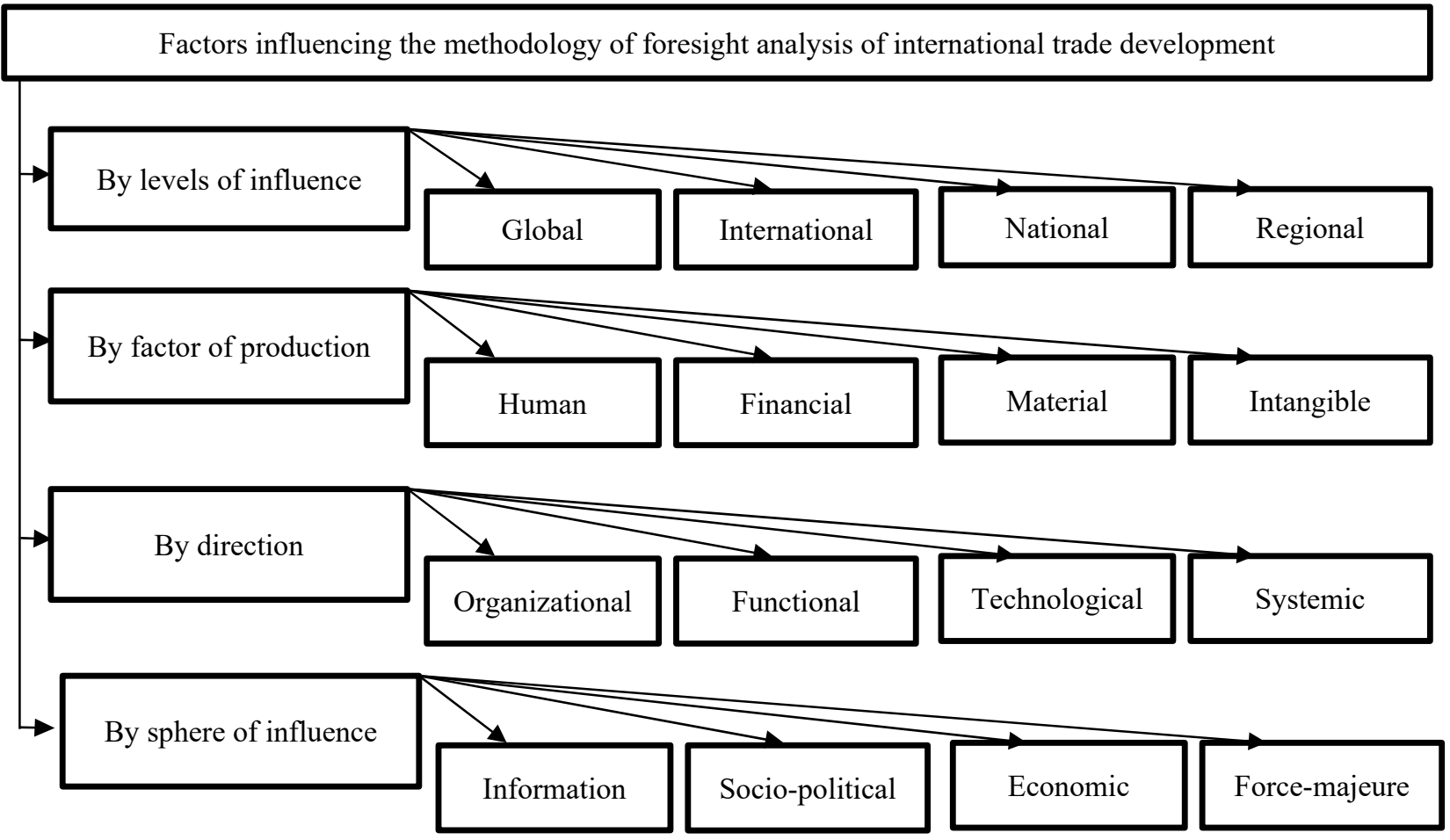

Figure 1. The set of factors influencing the methodology of foresight-analysis of international trade

Source: supplemented by the author's levels of factor selection and adaptation to international trade

Each group of endogenous and exogenous factors directly or indirectly influences decision-making when applying the foresight methodology for the development of international trade. The effectiveness and harmony of the methodology depends on the effective identification of influencing factors and relevant targeted motives, i.e., the causes of actions and consequences that affect the functioning of international trade.
Figure 2 structures the author's vision for building a model for providing a methodology for foresightanalysis of international trade.

The first segment of the methodology of foresightanalysis of the development of international trade defines the principles, objectives and functions that will achieve a certain goal of the study. The multicomponent set of strategic guidelines includes the appropriate standards, 


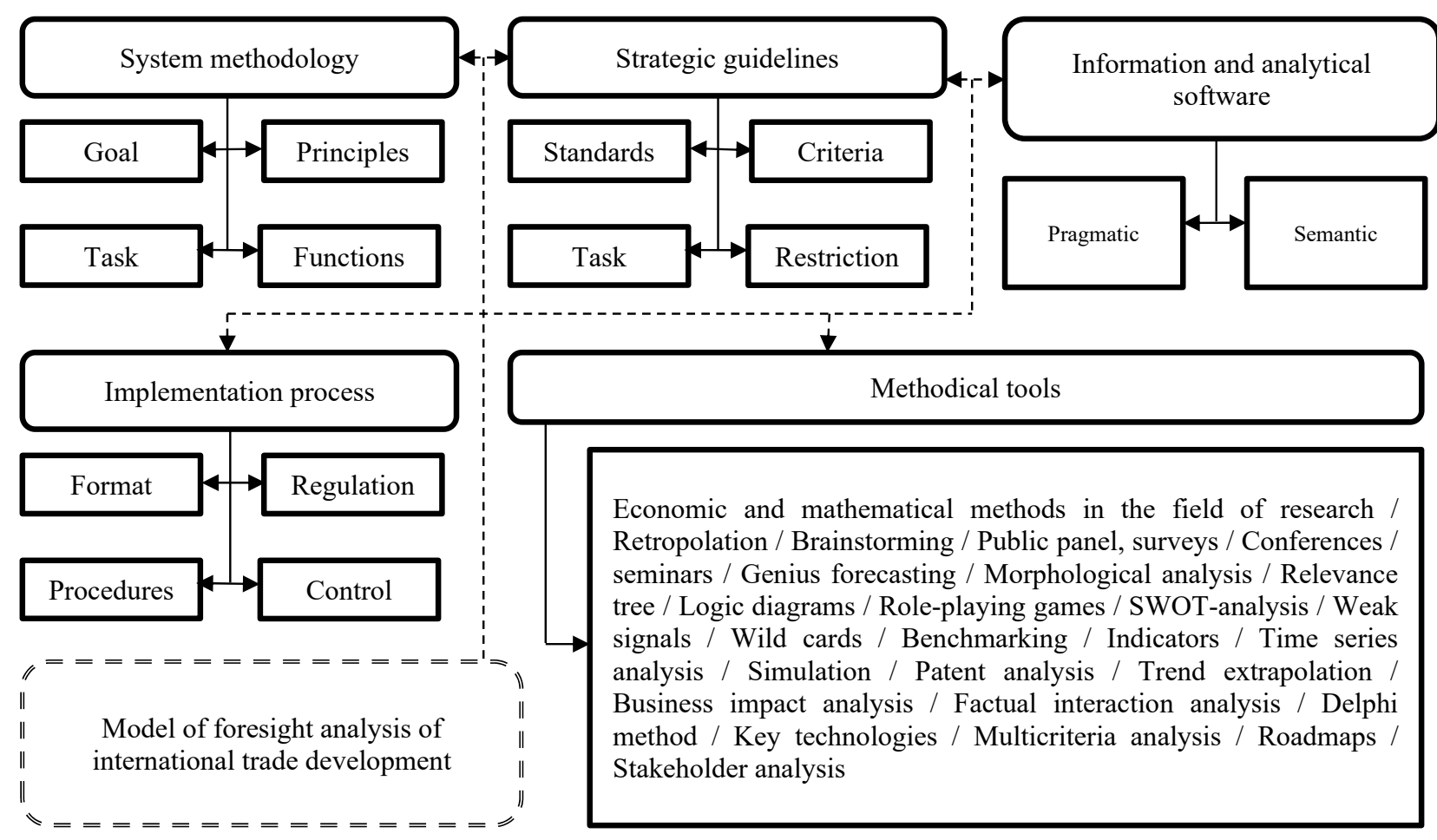

Figure 2. Model of foresight-analysis of international trade development

Source: formed by the author and adapted to the needs of the methodology of foresight-analysis of the development of international trade on the basis of (Rogachevskii, 2020)

parameters, criteria and constraints of the study, which are defined in the second segment. Information and analytical support of the foresight-analysis methodology and methodological tools, respectively, in the third and fourth segments.

Regarding the information-analytical support of the foresight-analysis methodology, according to Figure 2, it is analytical and synthetic information that is diagnosed, accumulated and transmitted to the relevant stakeholders on a systematic basis. The process of implementing the methodology of foresight-analysis of the development of international trade is carried out in the final segment, where we obtain the relevant results that will provide a strategy for the development of international trade in the future.

We draw attention to the fact that the process of building scenarios for the development of international trade is often subject to obstacles associated with negative environmental factors and problematic aspects in the mechanisms of building such scenarios, some of which are shown in Figure 3.

Thus, the scenarios used in the methodology of foresight-analysis should show possible alternatives to changes in the development of international trade, as well as the reverse impact of such developments on the international economy. Note that such scenarios are effectively complemented by the results of SWOTanalysis, brainstorming, patent analysis, the study of cross-interactions, etc.
It should be emphasized that the construction of scenarios is the basis for forecasting future consequences of the specifics of international trade and serves as an appropriate, timely and qualified foundation for the application of methods for predicting their consequences. At the same time, the structured system of methodological tools of the methodology of foresightanalysis is constantly changing, so it is advisable to accumulate experience in their practical application in research on international trade, including in the face of pandemic challenges and financial crises.

\section{Adaptation of the system of economic indicators to the needs of foresight-analysis of the development of international trade}

The variety of foresight methods poses an important task for the organization of this type of research, i.e., choose the most appropriate of the available, in terms of a particular study, the methods of optimal combination of such methods. In scientific literature, the following approaches to the formation of a combination of research methods are widespread: "triangle of foresight" or "diamond of foresight" (Popper, Georghiou, Miles, Keenan, 2010). Near each of the vertices of the corresponding figures there are depicted the methods that best meet the characteristics of this vertex, in particular, in the "foresight triangle" vertices correspond to the following features: expertise, creativity, 


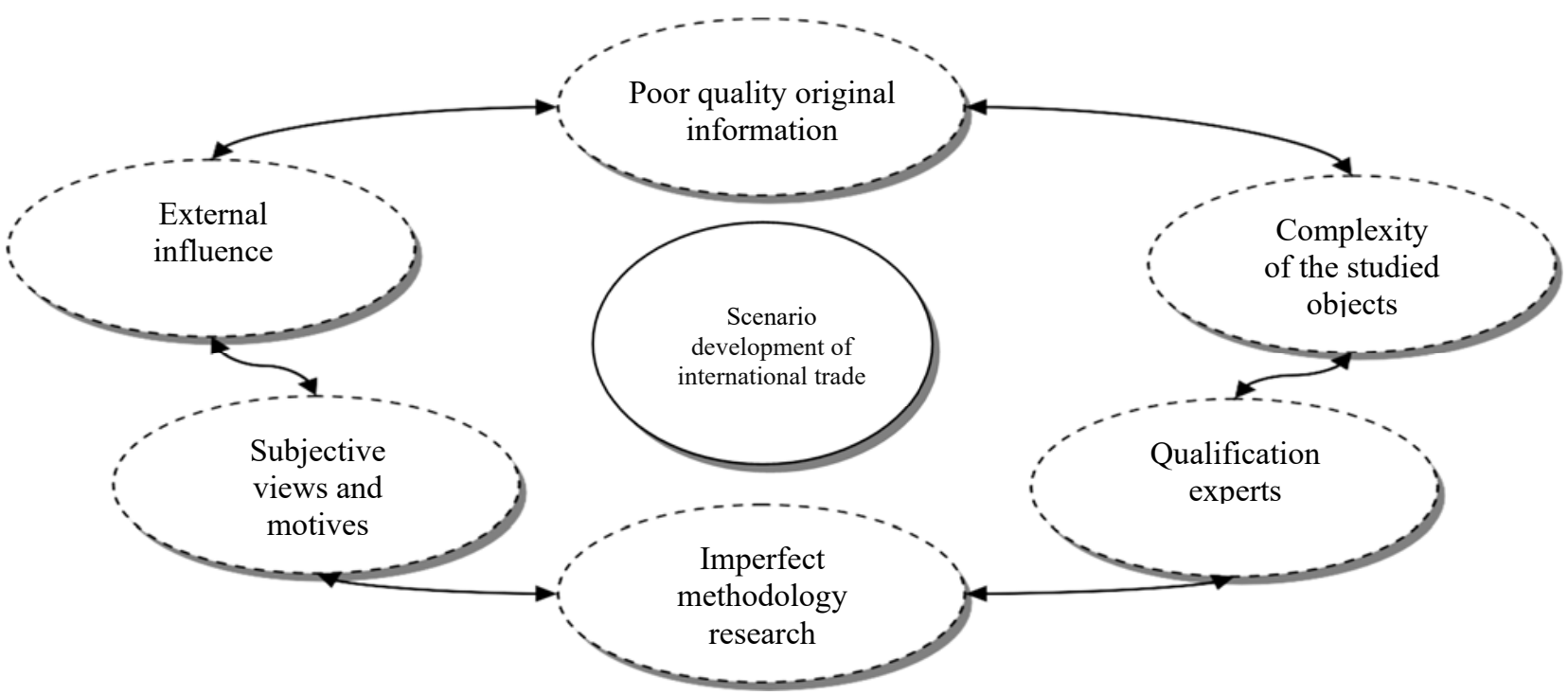

Figure 3. Negative factor influencing the scenario building process development of international trade

Source: author's generalization (Georghiou, 2008)

interaction. The combined application of methods with appropriate characteristics, as methodically provided, helps to ensure the most effective foresight of the study. In accordance with the requirements of the "foresight triangle" method, the study should combine, for example, interview methods, essays, influence matrices. The combination of several forecasting methods makes it possible to use their advantages and form the most accurate forecasts possible.

To conduct it, it is important to consider the main methods of financial forecasting and choose those that will help build a forecast of international trade (Table 2).

Thus, today there are many forecasting methods that have different advantages and disadvantages, so in the preparatory stage of a specific study on the development of international trade, you need to choose the ones that best meet the requirements of the study. Typical economic indicators within the foresight-analysis of the development of international trade are specific and require their own composition and structuring.

It is worth noting that the prerequisite for the successful positioning of any country in the world market and gaining tangible benefits from globalization effects is the use of economic and mathematical methods for forecasting the development of its foreign trade. In conditions of international instability, the traditional economic and statistical apparatus loses its relevance and requires the involvement of a modern arsenal of mathematical tools.

Particular attention should be paid to substantiating trends and patterns of economic processes under the influence of unexpected factors of non-economic nature, in particular such as socio-political, informational (shown in Figure 1), which increasingly determine the structure and dynamics of world economic processes. At the present stage of development, international trade clearly demonstrates its dependence on both objective

Table 2

Classification of types of foresight-analysis of international trade development and their characteristics

\begin{tabular}{|c|l|l|}
\hline Type & \multicolumn{1}{|c|}{ Kind } & \multicolumn{1}{|c|}{ Characteristic } \\
\hline Qualitative & $\begin{array}{l}\text { Retropolation / Brainstorming / Public panel, polls / } \\
\text { Conferences / seminars / Genius forecasting / Morphological } \\
\text { analysis / Relevance tree / Logic diagrams / Role games / } \\
\text { SWOT analysis / Weak signals / Wild cards }\end{array}$ & $\begin{array}{l}\text { They attach special importance to events and } \\
\text { perceptions. Such an interpretation tends to be based } \\
\text { on subjectivity or creativity, which is difficult to confirm. }\end{array}$ \\
\hline Quantitative & $\begin{array}{l}\text { Benchmarking / Bibliometrics / Indicators / Time series analysis } \\
\text { / Modeling / Patent analysis / Trend extrapolation / Business } \\
\text { impact analysis }\end{array}$ & $\begin{array}{l}\text { Apply variable and statistical studies using or generating } \\
\text { reliable data. }\end{array}$ \\
\hline Mixed & $\begin{array}{l}\text { Economic and mathematical methods in the field of research / } \\
\text { Analysis of the mutual influence of factors / Delphi method / } \\
\text { Key technologies / Multicriteria analysis / Road maps / Analysis } \\
\text { of stakeholders }\end{array}$ & $\begin{array}{l}\text { Mathematical principles are used to determine } \\
\text { the number of subjective, rational judgments and points } \\
\text { of view of experts. }\end{array}$ \\
\hline
\end{tabular}

Source: updated by the author based on (Georghiou, 2008) 
factors in the formation of the state's export potential and on factors of a subjective non-economic nature primarily socio-political. It is advisable to find adequate tools for modern international instability analysis and forecasting of the dynamics and structure of Ukraine's foreign trade.

Given the lack of experience in using foresight-analysis to forecast the development of international trade and, accordingly, developments in this area, we propose to supplement the structure of the methods presented in Table 1, the following group of economic indicators that assess the level of foreign trade (Trade) Statistical Guide, 2017) based on statistical methods (1-8):

- Openness of the economy $(O E)$ :

$$
E O=\frac{\text { Export }}{\text { Gross Domestic Product }} \times 100 \% \text {; }
$$

- Terms of trade (TT):

$$
T T=\frac{\text { Export price index }}{\text { Import price index }}
$$

- Coefficient of import dependence ( $\mathrm{Cid})$ :

$\mathrm{Cid}=\frac{\text { The volume of } \text { imports of the } i-\text { th goods of } j-\text { th country }}{\text { Import } p \text { Consumption of } i-\text { product in the } j-\text { th country }}$

- Import quota (IQ):

$$
I Q=\frac{\text { Import }}{\text { Gross Domestic Product }} \times 100 \% \text {; }
$$

- Export diversification index $\left(I_{e d}\right)$ :

$$
I_{e d}=\frac{\sum_{i=1}^{n}\left|h_{i j-} h_{i}\right|}{2}
$$

where $h_{i j}$ is the $i$-th share of goods in total exports of the country j;

$h_{i}$ is the share of the $i$-th commodity in total world exports.

- Net trade index $\left(I_{n t}\right)$ :

$$
I_{n t}=\frac{\left(E_{i}-I_{i}\right)}{\left(E_{i}+I_{i}\right)} \text {, }
$$

where $E_{i}$ is the export of goods $i$;

Ii is the import of goods $i$.

- Index of geographical concentration of exports (or imports) of goods $\left(I_{g c}\right)$ :

$$
I_{g c}=\sqrt{\sum_{i=1}^{n}\left(\frac{x_{i}^{k}}{x^{k}}\right)^{2}},
$$

where $x_{i}^{k}$ is the volume of exports (imports) of goods $k$ to the country $i$;

$x^{k}$ is the world exports (imports) of goods $\kappa$;

$n$ is the number of exporting countries (importers).

- Index of physical volume $\left(I_{p h}\right)$

$$
I_{p h}=\frac{\sum q_{1} p_{0}}{\sum q_{0} p_{0}},
$$

where $q_{1}$ is the price of goods in the base period;

$q_{0}$ is the price of the goods in the period under study; $p_{0}$ is the quantity of goods in the base period.

A consolidated analysis of this group of indicators (1-8) will allow for both comparative and summary analysis of international trade based on individual indicators of its development in the studied countries and will serve to improve the quality of foresightanalysis in the study data set for further forecasting.

\section{Conclusions}

Foresight-analysis is an effective method of strategic management in the field of macroeconomics to analyze the development of international trade, as its qualitative application can solve a number of issues related to forecasting.

Foresight has common and different features with forecasting, they are not identical concepts. The peculiarity of foresight-analysis is the focus on the development of practical measures aimed at approximating the desired scenario and involving a wide range of specialists. In addition, the foresight methodology helps not only to see the forecasted future, but also to adjust it in time.

The system of classifications of foresight-analysis allows its application not only at the national level of forecasting the development of trade, but also internationally. Foresight methodology is widely used in countries around the world as a key tool for developing and implementing research and innovation policies, including in the field of international trade and information base to justify strategic decisions for government and intergovernmental global and regional organizations, management of multinational corporations, science and the public.

When applying the methodology of foresightanalysis of the development of international trade, it is necessary to take into account the purposeful influence of endogenous and exogenous factors, classified by levels of influence: global, international, national, regional; by factor of production: human, financial, material, intangible; by orientation: organizational, functional, technological, system; by sphere of influence: informational, socio-political, economic, force majeure.

The structured model of providing the methodology of foresight-analysis of international trade development includes the following components: system methodology (purpose, tasks, principles, functions), strategic guidelines (standards, criteria, assignments, restrictions), information and analytical support (pragmatic and semantic), implementation process (format, regulations, procedures, control) and a set of methodological tools. Methodological tools include: economic and mathematical methods in the field of research, retropolation, brainstorming, public panel, surveys, conferences / seminars, genius forecasting, morphological analysis, relevance tree, logic diagrams, 
role-playing games, SWOT-analysis, weak signals, wild cards, benchmarking, bibliometrics, indicators, time series analysis, modeling, patent analysis, trend extrapolation, business impact analysis,

The following factors can have a negative impact on the process of building a scenario for the development of international trade: poor initial information, external influence, complexity of the studied objects, qualification of researchers and experts, imperfect research methodology, subjective views and motives.

The combined application of methods (quantitative, qualitative, mixed) in the foresight-analysis of the development of international trade provides maximum efficiency. The selection of methods is carried out at the preparatory stage of a particular study and must meet its requirements. Typical economic indicators within the foresight-analysis of the development of international trade are transformed into specific ones and require their own composition and structuring. The addition of the structure of economic methods of foresightanalysis by a group of economic indicators that assess the level of development of foreign trade of a country is substantiated and proposed. Such indicators are as follows: openness of the economy, terms of trade, coefficient of import dependence, import quota, export diversification index, net trade index, index of geographical concentration of exports (or imports) of goods, Index of physical volume.

\section{References:}

Foresight Group (2021). Un Global Compact: Communication on Progress. Avaible at: https:9/www.foresightgroup.eu/media/i3sjmpuv/foresight-group-llp-un-global-compact-communication-onprogress.pdf (accessed June, 28, 2021)

Yanch, E. (1974). Prohnozyrovanye nauchno-tekhnycheskoho prohressa [Scientific and technical forecasting progress]. Moscow: Progress. (in Russian)

Wells, H. (1932). Wanted - Professors of Foresight! Aired by the BBC on 19 ovember, 1932 Avaible at: https://bit.ly/ 3qtRYBe (accessed June, 28, 2021)

Habegger, B. (2010). Strategic foresight in public policy: reviewing the experiences of the UK, Singapore and the Netherlands. Futures, 42, 49-58.

Popper, R., Keenan, M., Miles, I., Butter, M., \& Sainz, G. (2007). Global Mapping Report 2007, European Foresight Monitoring Network report to the EU. Avaible at: https://bit.ly/2T7zMBs (accessed June, 28, 2021)

Cuosa, T. (2011). Practicing strategic foresight in government. The cases of Finland, Singapore and European Union. Singapore: S.Rajaratnam Studies.

Kuzyk, B., Kushlin, V., \& Yakovets, Y. (2006). Prohnozyrovanye y stratehycheskoe planyrovanye sotsyalnoэkonomycheskoho razvytyia [Forecasting and strategic planning of socio-economic development]. Moscow: Economics. (in Russian)

Martin, B. (1995). Foresight in science and technology. Technology Analysis and Strategic Management, 7 (2), 139-168.

Heraud, J. A., \& Cuhls, K. (1999). Current Foresight Activities in France, Spain and Italy. Technological. Forecasting and Social Change, 60, 55-70.

UNIDO (2005). Techniligy Foresight Manual. Organization and Methods. Avaible at: https://bit.ly/3A3IiSt (accessed June, 28, 2021)

Sokolov, A. (2007). Forsait: Vzghliad v budushchee [Foresight: A Look into the Future]. Foresight Journal, 1 (1), 10-11. (in Russian)

Gretchenko, A. (2010). Forsait kak ynnovatsyonnыi ynstrument prohnozyrovanyia y realyzatsyy nauchnыkh y tekhnolohycheskykh pryorytetov [Foresight as an innovative tool for forecasting and implementing scientific and technological priorities]. Bulletin of the Siberian State Aerospace University, 1, 34-39. (in Russian)

Eurasian Higher Business School (2021). Available at:https://emasglobe.com (accessed June, 28, 2021).

Li S-S, Kang M-H, Lee L-C (2009). Developing the evaluation framework of technology foresight program: lesson learned from European countries, Atlanta Conference on Science and Innovation Policy, Atlanta Conference on Science and Innovation Policy.

Dumanska, I. (2021). Quality assessment of business strategy in international trade: indicators and parameters. Baltic Journal of Economic Studies, 7 (2), 57-64. https://doi.org/10.30525/2256-0742/2021-7-2-57-64

Kizim, M., Matyushenko, I., Shostak, I., \& Danova, M. (2015). Forsait-prohnozuvannia priorytetnykh napriamiv rozvytku nanotekhnolohii i nanomaterialiv u krainakh svitu y Ukraini [Foresight-forecasting of priority strains in the development of nanotechnology and nanomaterials in the lands of the world of Ukraine]: monograph. Kherson: $\mathrm{VD} \ll \mathrm{INZHEK} \gg$. (in Ukrainian)

Luther, W. (2004). International Strategy and Foresight Report on Nanoscience and Nanotechnology, VDI Technologiezentrum GmbH, Dusseldorf.

Fedulova, L. (2008). Forsait: suchasna metodolohiia tekhnolohichnoho prohnozuvannia [Foresight: the current methodology of technological forecasting]. Economics and Forecast, 3, 106-120. (in Ukrainian)

United Nations Commission on Science and Technology for Development Strategic (2014). Foresight for the Post-2015 Development Agenda, Geneva, Switzerland. 
Rogachevskii, O. (2020). Kontseptualna model zabezpechennia metodolohii forsaitu u stratehichnomu rozvytku natsionalnoi haluzi okhorony zdorovia [Conceptual model of safeguarding the methodology of force and strategic development of national health protection]. Ukrainian Journal of Applied Economics, 5 (3), 304-310. (in Ukrainian) Georghiou, L. (2003). Evaluating Foresight and Lessons for Its Future Impact., paper presented at The Second International Conference on Technology Foresight, 27-28 February, Tokyo.

Popper, R., Georghiou, L., Miles, I. and Keenan, M. (2010). Evaluating Foresight: Fully-Fledged Evaluation of the Colombian Technology Foresight Programme (CTFP), Cali: Universidad del Valle. 2010. Available at: http://community.iknowfutures.eu/pg/file/popper/view/2204/evaluating-foresight-fullyfleded-evaluation-of-ctfp (accessed June, 28, 2021)

European Commission (2017). DG Trade Statistical Guide. Luxembourg: Publications Office of the European Union, 2017. 